\title{
EFFECT OF EDUCATIONAL PROGRAM ON NURSES' KNOWLEDGE RELATED TO CARE OF PATIENTS UNDERGOING NASOGASTRIC TUBE FEEDING
}

\author{
Prof. Nabila A. Bedier, Dr. Amal Bakr Abo EL-Ata, Mariam Sabry Shehab \\ Department of Medical Surgical Nursing, Faculty of Nursing, Alexandria University, \\ Department of Medical Surgical Nursing, Faculty of Nursing, Port Said University, \\ Department of Medical Surgical Nursing, Faculty of Nursing, Port Said University,
}

\begin{abstract}
Background: Implementing educational program on nurses' caring of patients undergoing nasogastric tube feeding is very important to prevent complications from feeding such as pulmonary aspiration, diarrhea, constipation, tube occlusion, displacement of the tube, abdominal cramping, nausea and vomiting, delayed gastric emptying and serum electrolyte imbalance. Aim of this study: This study was aiming to evaluate the effect of educational program on nurses' knowledge related to care of patients undergoing nasogastric tube feeding. It also aims to design, implement and evaluate an educational program for nurses' caring of patients undergoing nasogastric tube feeding. Research design: A quasi experimental design was used. Setting: The study was conducted in intensive care unit at Al-Azhar university hospital in new Damietta city. Subject: The study involved all available nurses' worked with patients undergoing nasogastric tube feeding in intensive care unit at Al-Azhar university hospital about (30 nurse). Tool of data collection: Data were collected using nurses' knowledge questionnaire sheet. Results: Total mean knowledge score regarding caring of patients undergoing nasogastric tube feeding were improved, as good score was $48.77 \pm 9.60$ preprogram while it reached $96.66 \pm 5.02$ after implementation of the educational program, $90.77 \pm 6.23$ after 3 months and 85.88 \pm 7.25 after 6 months later. Conclusion: Implementation of educational program for nurses' caring of patients undergoing nasogastric tube feeding significantly improved the nurses' total level of knowledge. Recommendation: The study recommended continuous educational programs should be planned on regular basis to nurses' about nasogastric tube feeding for enhancing nurses' knowledge and to achieve high quality of care.
\end{abstract}

Key Words: Educational Program, nurses, Nasogastric, Tube feeding, care, knowledge. 


\section{Introduction}

Nutrition is the science of food and its relationship to health. It is concerned primarily with the part played by nutrients in body growth, development and maintains. For every human being eating food is an enjoyment, which is the god gift. The person consumes food orally with proper nutrition; his health will be maintained optimally (Park, 2009).

Enteral feeding $(\mathrm{EF})$ techniques have developed over recent years with advanced technology to be more safe, efficient and comfortable means of providing nutritional support. Enteral feeding is a key component in the management of critically ill patients to tolerate feeding into the gastrointestinal tract. The reported benefits of enteral nutrition over parenteral nutrition include preservation of intestinal mucosa, optimal nutrient utilization, safe administration, and reduced cost (Adhikari, 2005).

Patients in the critical care setting are at high risk of malnutrition, due to the nature of their illness and their hyper-metabolic state. Their immune system is compromised, so they are at increased risk of infection and septicemia. Delayed healing and infections contribute to prolonged intensive care stay, increased mortality and morbidity and higher treatment costs. Therefore, correct nutrition from the onset of admission is imperative (Blackburn et al., 2010).

The complications with nasogastric tube feeding includes, pulmonary aspiration, diarrhea, constipation, tube occlusion, displacement of the tube, abdominal cramping, nausea and vomiting, delayed gastric emptying, serum electrolyte imbalance, increased respiratory quotient, fluid overload, hyperosmolar dehydration. So nurses must have adequate knowledge and good practice technique to minimize the complications. So nurses need the continuing educations and in-service programs regarding nasogastric tube feeding (Bullock et al., 2012 \& Potter and Perry, 2013). In-service education is one aspect of staff development, ongoing in all health care institution and refers to skill development for the direct care givers Leinonen, (2006) and (Rosenkoetter et al., 2007).

Staff development refers to the educational activities and functions provided to ensure competent performance and ability and fulfill the expectations of the job(Robinson et al., 2005 and Siciliano and Burrage, 2007). 
Continuing education include programs and activities designed for improving specific on the job skills (in-service or staff developments), for providing contents related to professional practice, for increasing personal or professional growth, and for increasing individual professional awareness. Programs or activities designed to improve or add a specific on the job skills primarily benefit the employee who may be willing to subsidize these activities (Johns, 2005, and Jackson, 2007).

\section{Aim of the study}

\section{This study aimed to:}

evaluate the effect of educational program on nurses' knowledge related to care of patients undergoing nasogastric tube feeding

\section{Research Questions:}

1- What is the knowledge of nurses' related to care of patients undergoing nasogastric tube feeding?

2- What is the effect of an educational program on nurses' knowledge related to care of patients undergoing nasogastric tube feeding?

\section{SUBJECTS AND METHODS}

\section{(I) TECHNICAL DESIGN}

\section{- Study Design}

A quasi experimental design was used in this study.

\section{- Study Settings}

The present study was conducted in intensive care unit at Al-Azhar university hospital in new Damietta city.

\section{Study Population:}

Included all available nurses' worked with patients undergoing nasogastric tube feeding in intensive care unit at Al-Azhar university hospital about (30 nurse).

\section{TOOL OF DATA COLLECTION}

Data were collected by using the following tool:-

Nurse's knowledge questionnaire sheet; it was developed by Ahmed (1997) and was adopted and modified by the researcher after reviewing of the related literature to assess nurse's knowledge related to care of patients undergoing nasogastric tube feeding. It compromised of two parts: 


\section{Part I:}

It included items related to demographic characteristics of the studied nurses as their name, age, sex, years of experience, training program and presence of protocol about nasogastric tube feedings care.

\section{Part II:}

It included 30 (M.C.Q) regarding nasogastric tube feeding; it covered nurses knowledge about initial nasogastric tube feeding principles (22question), consideration when giving intermittent feeding (4questions) and consideration when giving continuous feeding (4 questions).

\section{(II)ADMINISTRATIVE DESIGN}

Before conduction of the study, an official letter was sent from the faculty of nursing to the selected area of the study. The director of each setting was contacted and informed in order to obtain permission to include the nurses' on the present research.

\section{Ethical Considerations:}

Purpose and expected outcomes of the study were explained to each study subject. They were secured that all the gathered data will be used for the research purpose only, the study is harmless and their approval to participate is a prerequisite to be included in the study. Each subject was assured that they can quit/withdraw whenever they want.

\section{(III) OPERATIONAL DESIGN}

The operational design of the current study included the preparatory phase, content validity, pilot study and field work.

\section{Preparatory phase}

Development of the training program based on Shehab master thesis (2011), result of assessment of nurses' knowledge related to care of patients undergoing nasogastric tube feeding, identified needs in assessment phase and review of related literature. Contents of the program included : definition of gastrointestinal system, definition of nasogastric tube, importance of nasogastric tube, definition of enteral nutrition, factors for determining feeding route, types of feeding formula, component of feeding formula, indications of tube feeding, contraindications of tube feeding, complications of tube feeding, nursing care to NGT feeding patients. Then the researcher designed a plan for a training program implementation. This plan included twelve sessions to be 
implemented in twelve week. One session / week for 30 minutes to be repeated 3 times for each group. With 15 minutes break between each group.

Permission for conducting the study was taken from the head of nurse of critical care unit at Al-Azhar university hospitals after explaining the purpose, the time and the place of the study.

\section{- Pilot Study}

The pilot study was carried out after the development of the tool and before starting the data collection in order to test the clarity, feasibility, applicability and time required. It is carried out on $10 \%$ of the total sample size. It was conducted over a period of a week. After obtaining the results of pilot study, ambiguous items were omitted, required modifications as the manner of writing questions, arrangement of choices, sequences of questions were done and the final form was completed. Those included in the pilot study were excluded later from the sample.

\section{- Field Work}

- At the beginning; studied nurses divided into 3 groups (10 nurses each) then each group was gathered at the conference room separately for about half hours

- During this meeting the researcher: Explain the purpose of the study and Give each nurse handout includes theoretical content to facilitate remembers of knowledge about care of patients undergoing nasogastric tube feeding.

- The program was presented in clear and concise form using different teaching methods as discussions and lecture.

- At the end of the sessions each nurse were evaluated for knowledge using the tool.

- After 3 and 6 month after implementation of the program the nurses gathered in conference room again for evaluation the retention of information at the break time and evaluations were done using the same technique was used in first evaluation and same tool.

\section{(VI) STATISTICAL DESIGN}

The collected data organized, tabulated and statistically analyzed using statistical package for social science (SPSS) version 16 for windows, running on IBM compatible computer. Qualitative data (categorical data) were expressed as relative frequency (number) and percent distribution, and for comparison between groups, the Chi square $\left(\mathrm{X}^{2}\right)$ or Mann-Whitney test $(\mathrm{Z})$ was calculated. Quantitative data were 
expressed as mean $\pm \mathrm{SD}$, and for comparison between two means, the student ( $\mathrm{t}$ ) test was calculated. For interpretation of results, the $p$ value $\leq 0.05$ was considered significant

\section{Results}

Table (1) shows the socio-demographic characteristics of studied nurses. Most of the studied nurses had 20 years and less than 30 years (76.7\%). As regard graduation about two third of them had secondary diploma (63.3\%). As regard years of experience about half of them had more than four years of experience $(56.7 \%)$. All of the studied nurses did not have any previous training course about nasogastric tube feeding while only (3.3\%) of them had protocol about nasogastric tube feeding in studied critical care units.

Table (2) shows the difference in nurse's satisfactory knowledge regarding initial principle of nursing care to NGT feeding patients throughout the program intervention. The result indicated improvement of nurse's knowledge in various areas of nasogastric tube feeding, and their total score. These improvements were statistically significant were $(\mathrm{p}<0.001)$.

- The most prominent improvement was in the score of knowledge about position avoided during feeding. It reached $100 \%$ in the immediate post-test and reached to $96.7 \%$ first and second follows- up. The percentage of satisfactory knowledge continued to improve in the first follow-up with slightly decline after 3 and 6 months in nutrition $(86.7 \% \& 83.3 \%$ respectively), gastric $\mathrm{pH}$ after giving antacid $(86.7 \%$ \& $70 \%$ respectively), symptoms indicating abdominal distension (86.7\% and $80 \%$ respectively) and symptoms of electrolyte imbalance $(73.3 \%$ and $63.3 \%$ respectively).

Table (3) shows the difference in nurses 'satisfactory knowledge regarding consideration with intermittent feeding throughout the program intervention. The result indicated improvement of nurse's knowledge in all areas of intermittent feeding immediately and first follow-up, and their total score. These improvements were statistically significant were $(p<0.001)$. Except; in relation to knowledge about position of patient after meal $100 \%$ because this improvement was high in before, immediately, first and second follow-up. Meanwhile, nurses' knowledge score after 3 months and 6 months were slightly decline, compared to the immediate posttest in relation to rate of giving feeding $(83.3 \%)$. But nurse's level of knowledge were still significantly higher than the preprogram levels. 
Table, (4) shows the difference in nurse's knowledge regarding consideration with continuous feeding throughout the program intervention. The result indicated improvement of nurse's knowledge in various areas of continuous tube feeding, and their total score. These improvements were statistically significant $(p<0.001)$. Except in relation to position of patient during nutrition were $90 \%$ of the studied nursed had satisfactory level knowledge before program and this percentage increased immediate after to be $93.3 \%$ and after 3 months to be $96.7 \%$ and slightly decline after 6 months. Meanwhile, nurses knowledge score related to all items were slightly decline, compared to the immediate posttest and first follow-up, but studied nurse levels of knowledge were significantly higher than the preprogram levels.

Table, (5) shows difference in nurse's knowledge about NGT feeding through the program; there were significant difference in the total score of nurse's knowledge regarding nasogastric tube feeding throughout the program intervention between posttest and pre-program first follow up and pre and second follow up and pre-program. $(\mathrm{P}<0.001)$. A high statistical significant improvement in nurse's knowledge were found between the immediate post-test and the pre-program level, between preprogram and 3month after and between pre-f6 were $(\mathrm{P}<0.001)$. There were no statistical significant difference between immediately post and first and second follow up were $(\mathrm{P}=0.31$ respectively). Also there was no statistical significant difference between first and second follow-up $(\mathrm{P}=1.0)$.

Table, (6) shows no statistical significance difference was found between nurses' total knowledge and their level of education, and age. The only statistical significance difference was found between nurses' total knowledge before program and their years of experience $(\mathrm{P}=0.023)$ 
Table (1): Distribution of the studied nurses according to their socio-demographic characteristics $(\mathrm{No}=\mathbf{3 0})$

\begin{tabular}{|c|c|c|c|}
\hline \multicolumn{2}{|r|}{ Items } & $\mathbf{N}$ & $\%$ \\
\hline \multirow{2}{*}{ Age } & $<20$ years & 7 & 23.3 \\
\hline & 20 to 30 years & 23 & 76.7 \\
\hline \multirow{2}{*}{ Social state } & Unmarried & 8 & 26.7 \\
\hline & Married & 22 & 73.3 \\
\hline \multirow{3}{*}{ Graduation } & Bachelor & 3 & 10.0 \\
\hline & technical health institute & 8 & 26.7 \\
\hline & secondary diploma & 19 & 63.3 \\
\hline \multirow{3}{*}{ Experience } & $<2$ years & 11 & 36.7 \\
\hline & 2 to 4 years & 2 & 6.7 \\
\hline & $>4$ years & 17 & 56.7 \\
\hline Had training & None & 30 & $100.0 \%$ \\
\hline \multirow{2}{*}{ Protocol of care } & Yes & 1 & 3.3 \\
\hline & No & 29 & 96.7 \\
\hline
\end{tabular}


Table (2): Differences in nurse's satisfactory knowledge regarding initial principles of nursing care to NGT feeding patients throughout the program intervention. $(\mathrm{No}=30)$

\begin{tabular}{|c|c|c|c|c|c|c|c|c|c|c|}
\hline \multirow[t]{2}{*}{ Items } & \multicolumn{2}{|c|}{$\begin{array}{c}\text { Before } \\
\text { program }\end{array}$} & \multicolumn{2}{|c|}{$\begin{array}{c}\text { Immediately } \\
\text { after }\end{array}$} & \multicolumn{2}{|c|}{$\begin{array}{l}3 \text { months } \\
\text { after }\end{array}$} & \multicolumn{2}{|c|}{$\begin{array}{l}6 \text { months } \\
\text { after }\end{array}$} & \multirow[t]{2}{*}{ 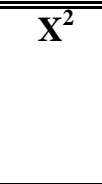 } & \multirow[t]{2}{*}{$\mathbf{p}$} \\
\hline & $\mathrm{n}$. & $\%$ & n. & $\%$ & n. & $\%$ & n. & $\%$ & & \\
\hline $\begin{array}{l}\text { Indications of } \\
\text { nasogastric tube }\end{array}$ & 0 & $0.0 \%$ & 26 & $86.7 \%$ & 24 & $80.0 \%$ & 23 & $76.7 \%$ & 62.78 & $<0.001 * *$ \\
\hline $\begin{array}{l}\text { Precautions for } \\
\text { feeding }\end{array}$ & 17 & $56.7 \%$ & 30 & $100.0 \%$ & 29 & $96.7 \%$ & 28 & $93.3 \%$ & 31.73 & $<0.001 * *$ \\
\hline $\begin{array}{l}\text { Contraindications of } \\
\text { NGT }\end{array}$ & 22 & $73.3 \%$ & 30 & $100.0 \%$ & 28 & $93.3 \%$ & 26 & $86.7 \%$ & 11.32 & $0.010 * *$ \\
\hline $\begin{array}{l}\text { Duration of NGT } \\
\text { nutrition }\end{array}$ & 1 & $3.3 \%$ & 30 & $100.0 \%$ & 26 & $86.7 \%$ & 25 & $83.3 \%$ & 80.25 & $<0.001 * *$ \\
\hline $\begin{array}{l}\text { Investigations done } \\
\text { before feeding }\end{array}$ & 3 & $10.0 \%$ & 30 & $100.0 \%$ & 27 & $90.0 \%$ & 25 & $83.3 \%$ & 73.69 & $<0.001 * *$ \\
\hline $\begin{array}{l}\text { Position avoided } \\
\text { during NGT feeding }\end{array}$ & 23 & $76.7 \%$ & 30 & $100.0 \%$ & 29 & $96.7 \%$ & 29 & $96.7 \%$ & 14.77 & $0.002 *$ \\
\hline $\begin{array}{l}\text { Gastric pH after } \\
\text { giving antacids }\end{array}$ & 4 & $13.3 \%$ & 28 & $93.3 \%$ & 26 & $86.7 \%$ & 21 & $70.0 \%$ & 52.86 & $<0.001 * *$ \\
\hline $\begin{array}{l}\text { Symptoms indicating } \\
\text { abdominal distension }\end{array}$ & 7 & $23.3 \%$ & 28 & $93.3 \%$ & 26 & $86.7 \%$ & 24 & $80.0 \%$ & 44.97 & $<0.001 * *$ \\
\hline $\begin{array}{l}\text { Method for avoiding } \\
\text { fluid imbalance }\end{array}$ & 30 & $100.0 \%$ & 30 & $100.0 \%$ & 30 & $100.0 \%$ & 30 & $100.0 \%$ & $\mathrm{a}$ & \\
\hline $\begin{array}{l}\text { Principle for giving } \\
\text { medications }\end{array}$ & 7 & $23.3 \%$ & 28 & $93.3 \%$ & 28 & $93.3 \%$ & 25 & $83.3 \%$ & 52.15 & $<0.001 * *$ \\
\hline $\begin{array}{l}\text { Most common } \\
\text { problems done for } \\
\text { NGT feed pt. }\end{array}$ & 16 & $53.3 \%$ & 27 & $90.0 \%$ & 26 & $86.7 \%$ & 26 & $86.7 \%$ & 16.32 & $0.001 * *$ \\
\hline $\begin{array}{l}\text { Symptoms of } \\
\text { electrolytes imbalance }\end{array}$ & 1 & $3.3 \%$ & 28 & $93.3 \%$ & 22 & $73.3 \%$ & 19 & $63.3 \%$ & 55.54 & $<0.001 * *$ \\
\hline Total & 10 & $33.3 \%$ & 30 & $100.0 \%$ & 30.0 & $100.0 \%$ & 30.0 & $100.0 \%$ & 72.0 & $<0.001 * *$ \\
\hline
\end{tabular}


Table (3): Differences in nurse's satisfactory knowledge about consideration with intermittent feeding throughout the program intervention. $(\mathrm{No}=30)$

\begin{tabular}{|c|c|c|c|c|c|c|c|c|c|c|}
\hline \multirow[t]{2}{*}{ Items } & \multicolumn{2}{|c|}{$\begin{array}{c}\text { Before } \\
\text { Program }\end{array}$} & \multicolumn{2}{|c|}{$\begin{array}{c}\text { Immediately } \\
\text { After }\end{array}$} & \multicolumn{2}{|c|}{$\begin{array}{c}\text { months } \\
\text { After }\end{array}$} & \multicolumn{2}{|c|}{$\begin{array}{c}6 \text { months } \\
\text { after }\end{array}$} & \multirow[t]{2}{*}{ 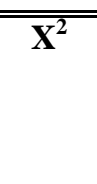 } & \multirow[t]{2}{*}{ p } \\
\hline & $\mathrm{n}$ & $\%$ & $\mathrm{n}$ & $\%$ & $\mathrm{n}$ & $\%$ & $\mathrm{n}$ & $\%$ & & \\
\hline $\begin{array}{l}\text { Rate of giving } \\
\text { feeding }\end{array}$ & 2 & $6.7 \%$ & 28 & $93.3 \%$ & 25 & $83.3 \%$ & 25 & $83.3 \%$ & 65.70 & $<0.001 * *$ \\
\hline $\begin{array}{l}\text { The quantity of } \\
\text { water after meal }\end{array}$ & 22 & $73.3 \%$ & 29 & $96.7 \%$ & 28 & $93.3 \%$ & 27 & $90.0 \%$ & 9.38 & $0.025^{* *}$ \\
\hline $\begin{array}{l}\text { Patient is leaved } \\
\text { in sitting } \\
\text { position after } \\
\text { NGT nutrition }\end{array}$ & 28 & $93.3 \%$ & 30 & $100.0 \%$ & 30 & $100.0 \%$ & 30 & $100.0 \%$ & 6.10 & 0.11 \\
\hline $\begin{array}{l}\text { Investigation of } \\
\text { food in the } \\
\text { stomach }\end{array}$ & 20 & $66.7 \%$ & 30 & $100.0 \%$ & 29 & $96.7 \%$ & 27 & $90.0 \%$ & 19.73 & $<0.001 * *$ \\
\hline
\end{tabular}

Table (4): Differences in nurses' satisfactory knowledge about consideration with continuous feeding throughout the program intervention $(\mathrm{No}=30)$

\begin{tabular}{|c|c|c|c|c|c|c|c|c|c|c|}
\hline \multirow[t]{2}{*}{ Items } & \multicolumn{2}{|c|}{$\begin{array}{c}\text { Before } \\
\text { Program }\end{array}$} & \multicolumn{2}{|c|}{$\begin{array}{c}\text { Immediately } \\
\text { After }\end{array}$} & \multicolumn{2}{|c|}{$\begin{array}{c}\text { months } \\
\text { After }\end{array}$} & \multicolumn{2}{|c|}{$\begin{array}{c}6 \text { months } \\
\text { after }\end{array}$} & \multirow[t]{2}{*}{$\overline{\overline{X^{2}}}$} & \multirow[t]{2}{*}{ p } \\
\hline & $\mathrm{n}$ & $\%$ & $\mathrm{n}$ & $\%$ & $\mathrm{n}$ & $\%$ & $\mathrm{n}$ & $\%$ & & \\
\hline $\begin{array}{l}\text { Position of } \\
\text { patient } \\
\text { during } \\
\text { nutrition }\end{array}$ & 27 & $90.0 \%$ & 28 & $93.3 \%$ & 29 & $96.7 \%$ & 27 & $90.0 \%$ & 1.32 & 0.72 \\
\hline $\begin{array}{l}\text { Investigation } \\
\text { of food in the } \\
\text { stomach }\end{array}$ & 0 & $0.0 \%$ & 28 & $93.3 \%$ & 23 & $76.7 \%$ & 23 & $76.7 \%$ & 66.69 & $<0.001 * *$ \\
\hline $\begin{array}{l}\text { Care of tube } \\
\text { after feeding }\end{array}$ & 0 & $0.0 \%$ & 27 & $90.0 \%$ & 23 & $76.7 \%$ & 21 & $70.0 \%$ & 60.53 & $<0.001^{* *}$ \\
\hline $\begin{array}{l}\text { Period of } \\
\text { changing } \\
\text { NGT feeding } \\
\text { set }\end{array}$ & 6 & $20.0 \%$ & 28 & $93.3 \%$ & 26 & $86.7 \%$ & 24 & $80.0 \%$ & 48.88 & $<0.001 * *$ \\
\hline Total & 0 & $0.0 \%$ & 26 & $86.7 \%$ & 27 & $90.0 \%$ & 26 & $86.7 \%$ & 77.17 & $<0.001 * *$ \\
\hline
\end{tabular}


Table (5): Differences in the total score of nurse's knowledge about NGT feeding throughout the program intervention $(\mathrm{No}=30)$

\begin{tabular}{|c|c|c|c|c|c|c|c|c|}
\hline \multirow[t]{2}{*}{ Items } & \multicolumn{2}{|c|}{$\begin{array}{c}\text { Before } \\
\text { Program }\end{array}$} & \multicolumn{2}{|c|}{$\begin{array}{c}\text { Immediately } \\
\text { After }\end{array}$} & \multicolumn{2}{|c|}{$\begin{array}{l}3 \text { months } \\
\text { After }\end{array}$} & \multicolumn{2}{|c|}{$\begin{array}{l}6 \text { months } \\
\text { after }\end{array}$} \\
\hline & $\mathrm{n}$ & $\%$ & $\mathrm{n}$ & $\%$ & $\mathrm{n}$ & $\%$ & $\mathrm{n}$ & $\%$ \\
\hline Satisfied $(\geq 75 \%)$ & 0 & $0.0 \%$ & 30 & $100.0 \%$ & 29 & $96.7 \%$ & 29 & $96.7 \%$ \\
\hline Dissatisfied $(<75 \%)$ & 30 & $100.0 \%$ & 0 & $.0 \%$ & 1 & $3.3 \%$ & 1 & $3.3 \%$ \\
\hline Mean \pm SD & \multicolumn{2}{|c|}{$48.77 \pm 9.60$} & \multicolumn{2}{|c|}{$96.66 \pm 5.02$} & \multicolumn{2}{|c|}{$90.77 \pm 6.23$} & \multicolumn{2}{|c|}{$85.88 \pm 7.25$} \\
\hline Post_pre & \multicolumn{8}{|c|}{$\mathrm{Z}=7.68, \mathrm{p}<0.001 * *$} \\
\hline F3_pre & \multicolumn{8}{|c|}{$\mathrm{Z}=7.42, \mathrm{p}<0.001 * *$} \\
\hline F6-Pre & \multicolumn{8}{|c|}{$\mathrm{Z}=7.42, \mathrm{p}<0.001^{* *}$} \\
\hline F3_post & \multicolumn{8}{|c|}{$\mathrm{Z}=1.0, \mathrm{p}=0.31(\mathrm{NS})$} \\
\hline F6- Post & \multicolumn{8}{|c|}{$\mathrm{Z}=1.0, \mathrm{p}=0.31(\mathrm{NS})$} \\
\hline F6_F3 & \multicolumn{8}{|c|}{$\mathrm{Z}=0.001, \mathrm{p}=1.0(\mathrm{NS})$} \\
\hline
\end{tabular}

Table (6): Comparison between nurse's mean score and standard deviation of the studied nurses in relation to care of patients with NGT feeding throughout the program intervention according to their (education, age \&years of experience) $(\mathrm{No}=30)$

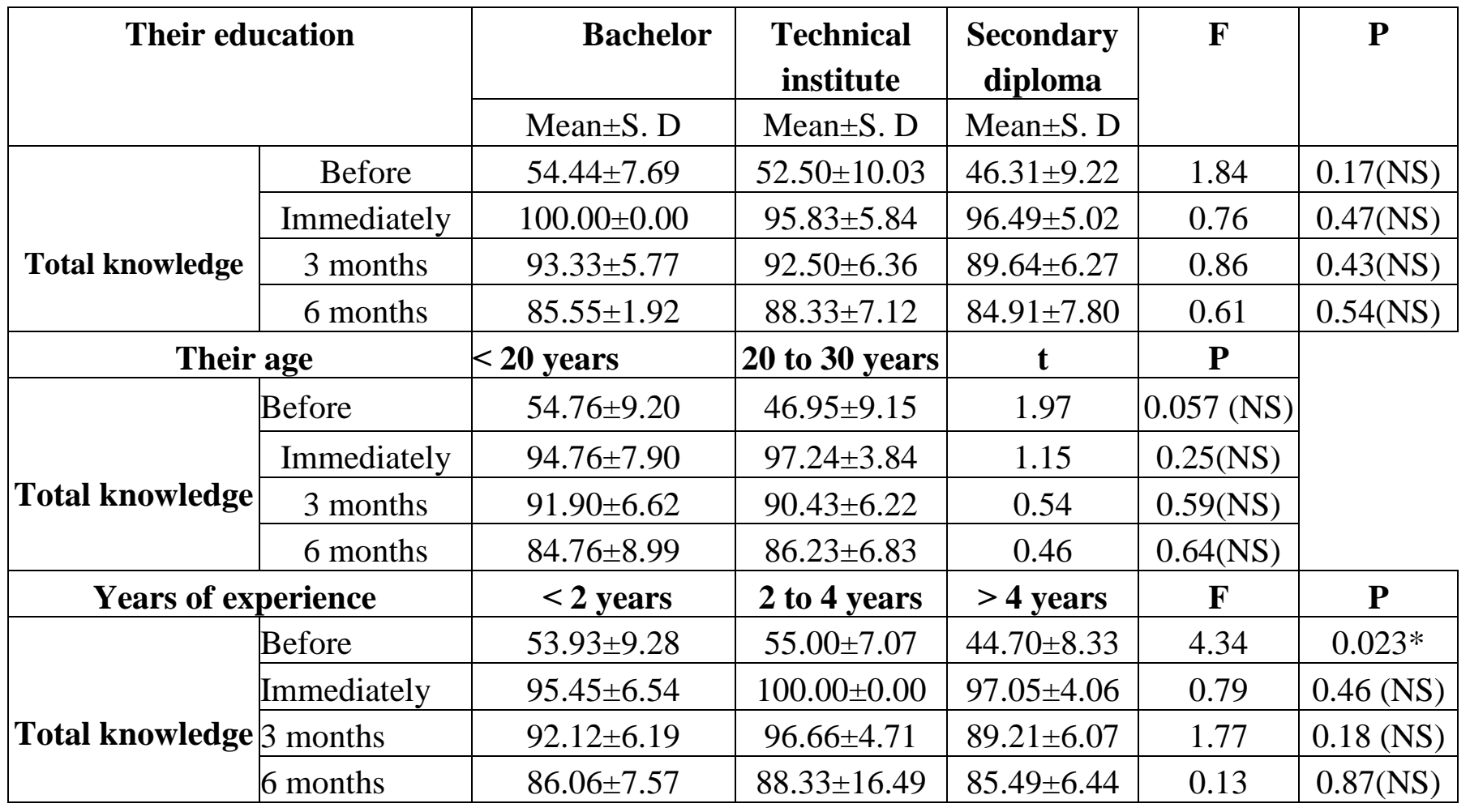




\section{Discussion}

The present study included 30 nurses, all of them were females. Most of them were 20 years and less than 30 years. Also the majority of nurses had secondary degree of education (diplom). This result agreed with Sobeh, (2010) who studied effect of educational program about the care of mechanically ventilated patients on the knowledge and skills performance of nurse's performance in intensive care units of hospitals in Port Said city. Also the majority of the studied nurses had more than 4 years of experience.

Regarding training program, it was found that all of the studied nurses did not had any training program or written protocol related to care of nasogastric tube feeding patients. Thus reflect a bad care was introduced to the patients before programs.

This finding were supported by Madigam et al., (2007), Grigges, (2005), and Kwekkeboom et al., (2006) who stressed that training programs were required to target the specific needs of nursing staff working at different care settings. On the same line Happel, (2005) stated that quality should begin with education and end with education.

As regard nurses' knowledge about caring of patients undergoing nasogastric tube feeding before program implementation, in the current study, almost all of studied nurses had statistically unsatisfied total basic knowledge about nasogastric tube feeding related to its indications, duration of NGT nutrition, investigations done before feeding, most common problems with feeding, symptoms of electrolyte disturbance, gastric $\mathrm{pH}$ after giving antacid and principles of giving medications.

This result might be due to that most of the studied nurses were diploma graduates, working since 13 years, without attending any in-service training program related to nasogastric tube feeding and their knowledge during school study years might be insufficient for such specialized service or forgotten in addition to their was lack of supervision and evaluation system for nurses' practice during their working. This pointed of area of deficient of continuing nursing education. 
This finding was in accordance with Shehab, (2011) and Ahmed, (1997) who found that all studied nurses' had statistical unsatisfactory level of knowledge about care provided to patients undergoing nasogastric tube feeding. They added that the reasons for nurses' unsatisfactory knowledge and practice were improper environment, lack of in-service training program of nursing staff, lack of nursing supervision and increased nurse patient ratio.

Moreover a systematic review provided clear evidence of an association between the numbers of registered nurses and patient outcomes in acute care settings Kane, (2007).In addition several studies concluded that each additional registered nurse per patient per day was associated with a $4 \%$ decrease in the number of deaths (Aiken, 2002, Needleman, 2002 and Grap, 2009).

From the analysis of 12 items of nurses' knowledge about care provided to patients undergoing nasogastric tube feeding after program implementation it was found that there was statically significant improvement in all items. The most prominent improvement was in the score of knowledge about position avoided during feeding and precautions of feeding. The percentage of satisfactory knowledge continued to improve in the first follow-up with slightly decline in knowledge related to gastric ph. after giving antacid and symptoms of electrolyte imbalance in the second follow up. According to nurses' knowledge about consideration with intermittent and continuous feeding it was found that there was highly statistically significant improvement in the total score of nurses' knowledge immediately, post 3 month and 6 month. The most prominent improvement in intermittent feeding was in the score of knowledge about position of patient after NGT nutrition immediately, first and second follow-up.

Theses finding were supported by El-Dosoky, (2008) and El-Ezaby, (2004) who concluded that there were statistically significant improvement in nurses' knowledge immediately, first and second evaluation after program implementation compared to preprogram level.

These finding were in explained by Walike et al., (2004) who reported that nurses' knowledge can directly influence the success of a nutritional support program with nasogastric tube feeding. Also this finding was supported by Herd rich and Lindsay, (2006) who asserted the positive effect and high impact of the teaching program on subject's knowledge after implementation of the program. 
Moreover, these results were on the same line with Seliman et al., (2011) who concluded that implementations of the enteral feeding guidelines and aspiration risk reduction algorithm achieved its goal of improvement and decrease in incidence of aspiration and other complications compared to patients who received the conventional unit car.

Moreover the finding of the present study revealed that the satisfactory level of nurses' knowledge total score were still high throughout the follow- up phase (3 months and six months) after implementation the program, these finding were in accordance with Shahin et al., (2012) who found that from the analysis of the mean scores of the participants' knowledge about enteral nutrition, reported that; the instructional program had a positive impact in the improvement of the nurses' knowledge about enteral nutrition and this improvement was sustainable after 1 and 2 months following the instructional program.

Regarding the age of participant, the results reveal that although no statistical significance difference was found between nurse's knowledge and their age groups. Nurses of age category of 20 and less than 30 years had the highest percentage in their score of knowledge immediately post program and preprogram level. The results contradicted with Shahen et al., (2012) who detected a positive statistically significant relation between post program knowledge score and age of participants; but the results agree with Mohamed \& Wafa, (2011) who reported that there were no significant statistically differences between knowledge score and age of participants.

Regarding level of education it was found that; there was no statistical significance difference was found between nurses' knowledge and their level of education. This results may due to most of the studied nurses were in the same age group and most of them were diploma nurse.

These results disagree with Shahin et al., (2012), Mohamed \& Wafa, (2011) and Penland, (2010). All of them found that; there was statistical significance relation between nurses' knowledge, and educational level of participant. 
Regarding years of experience the results of the current study showed that the only statistical significance difference was found between nurses' knowledge and their experience; where nurses with 2-4 years of experience had the highest percentage in their score of knowledge between immediately post programs and preprogram level.

The results were contradicted with Suchitra and Lakshmi, (2007). The study aimed to evaluate the impact of education on knowledge, attitudes regarding nosocomial infections among various categories of health care workers. The study reported that years of experience in the hospital significantly correlated to increased knowledge and attitudes among the various categories of staff.

Also these results agree with El-Dosoky, (2008) who reported that there were no statistically significance relation was found between nurses' knowledge and their age or experience and working areas.

\section{CONCLUSION}

In the light of the current study, it can be concluded that, the educational program provided for nurses' working in I.C.U unit at Al-Azhar University hospital significantly increased the level of their knowledge related to care of patients undergoing nasogastric tube feeding.

\section{RECOMMENDATIONS}

In the light of the findings of the current study the following recommendations are suggested:

1. Continuous educational programs (in-service education and workshops) should be planned on regular basis to nurses working on I.C.U about nasogastric tube feeding for enhancing nurses' knowledge to achieve high quality of care and this programs should made on free days so they don't interfere with nurse clinical work schedule.

2. Nurses working with patients undergoing nasogastric tube feeding must have a specific job description to know exactly their responsibility in clinical area. 
3. Nursing school curriculum must include all information about tube feeding including; definition, indications, insertion, removal, feeding, irrigations and role of nurses in providing care to patients fed with nasogastric tube.

\section{References}

Adhikari, N. (2005): Nutrition for critically ill patients. Critical care, 9(3): 9-10.

Ahmed, W.N. (1997): Assessment of nurse's knowledge and practice in relation to nasogastric tube feeding. Master degree. Faculty of Nursing. Alexandria University, P.P. 81-91.

Aiken L.H. (2002): Hospital nurse staffing and patient mortality, nurse burnout, and job dissatisfaction. Journal of the American Medical Association, 288(16): 1987-1993.

Blackburn, G., Wollner, S., Bistrian, B. (2010): Nutrition support in the intensive care unit: an evolving science. Archives of Surgery, 145(6):533-8.

Bullock, Clark, Malone, J. (2012): Adult Nursing Practice Using Evidence in Care. Oxford. P.424.

El-dosoky, E.I. (2008): Assessment of nurse knowledge and practice about measure to prevent deep venous thrombosis among hospitalized patient in general hospitals of Port Said hospital. Unpublished Master Thesis. Faculty of Nursing, Suez Canal University, Egypt.

El-Ezaby, H.H. (2004): Effect of a Training Program Developed for Nurses about Universal Precaution for Infection control in Health Care Centers in Port Said. Unpublished Doctorate Thesis, Faculty of Nursing, Suez Canal University, Egypt.

Grap, M.J. (2009): Clinical pearls. Am J Crit Care.; 18(2):104.

Grigges, R. (2005): ROTC Training Teaches Nursing Students Critical Thinking Skills. Nurse-Educ., 30 (1): p.p. 37-39.

Happell, B. (2005): Education For Life: The Evaluation Of An Innovative Approach To Facilitate Ongoing. accessed at 20/3/2011.

Herdrich, B., and Lindsay, A. (2006): Nurse Residency Program: Redesigning the Transition into Practice. J. Nurses -Staff-Dev., 22(2):p.p.55-62.

Jackson, S.E. (2007): The Influence of Managed Care on U.S. Baccalaureate Nursing Education Programs. Journal- Of - Nursing- Education, 45 (2):p.p.67:74.

Johns, R.A (2005): Prioritizing To Safeguard the Integrity of Nurse Education. Nurs. Times, 101 (34): p.p.26-27. 
Kane, R. (2007): The association of registered nurse staffing levels and patient outcomes: Systematic review and meta-analysis. Medical Care. ; 45 (12) 1195-1204.

Kwekkeboom. K.L., Vahl, C., and Eland, J. (2006): Impact Of Volunteer Companion Program On Nursing Student's Knowledge And Concerns Related To Palliative Care. J. Palliat- Med., 9(1): p.p. 90-99.

Leinonen, S.J. (2006):International Nursing Exchange Program. Journal- OfContinuing- Education -In-Nursing, 37(1):p.p.16-20.

Madigam, S. M., Fleming, P., McCann, S., Wright, M.E., Nac Auley, D. (2007): "Primary care and General Practitioners Involvement in Enteral Tube Feeding At Home: A qualitative study". BMC Fam Practi, May 15th.

Needleman, J. (2002): Nurse- staffing levels and the quality of care in hospitals. New England Journal of Medicine, 346(22): 1715-1722.

Park, K. (2009): "Preventive and Social Medicine", Nutrition and Health, (15 $\left.5^{\text {th }} \mathrm{ed}\right)$.

Potter and Perry. (2013): Fundamentals of Nursing. $\left(8^{\text {th }}\right.$ ed). Canada. P. 1022.

Robinson, K., Sportsman, S., Eschiti, V.S., Bradshaw, p., and Bol, T. (2005): Preparing Faculty and Students For An International Nursing Education Experience. Journal-Of-Continuing- Education- in Nursing, 37(1): p.p.21-29.

Rosenkoetter, M.M., Bradshaw, M., Kiernan, B.S., and Bowcutt, M.A. (2007): Nurse Scholars Programs. J. Nurs. Edu, 44(9): p.p. 426-431.

Seliman, A., El-Soussi, A., Sultan, M., and Othman, S. (2011): Effect of Implementing Nursing Guidelines for Tube feeding on the Occurrence of Aspiration among Critically Ill Patients. Journal of Nature and Science, 9(11): 164-173.

Shahin, M., Mohamed, W., and Sayd, M. (2012): Nurses Knowledge and Practices Regarding Enteral Nutrition at the Critical Care Department of Al- Manial University Hospital in Egypt: Impact of a Designed Instructional Program. Journal of American Science, 8 (11). 397- 404.

Shehab, M. (2011): Assessment the Nurses Performance in Providing Care to Patients Undergoing Nasogastric Tube in Suez Canal University Hospital. Master degree. Faculty of Nursing. Suez Canal University.

Siciliano, P., and Burrage, R. (2007): Chronic Pain inthe Elderly: A Continuing Education Program For Certified Nursing Assistant. Geriatr. Nurs., 26(4): p.p. 252-258.

Sobeh, D. (2010): Effect of an Educational Program about the care of Mechanically Ventilated Patients on the Knowledge and Skills performance of Nurses in Intensive Care 
Units of the hospitals in port -Said City. Doctorate degree. Faculty of Nursing. Port Said University.

Penland, K. (2010): The relationship between nurse nutrition knowledge and unintentional weight loss in nursing home residents. Dissertations of the University of Arizona: 1-142.

Suchitra, J., \& Lakshmi, D. (2007): Impact of education on knowledge, attitudes and practices among various categories of health care workers on nosocomial infections. Indian Journal of Medical Microbiology, 25:181-187

Mohamed, S., and Wafa, A. (2011): The effects of an educational program on nurse's knowledge and practice related to hepatitis c virus: a pretest and posttest quasi experimental design. Australian Journal of Basic and Applied Sciences, 5(11): 564-570. 


\section{تأثير البرنامج التعليمي علي معلومات الممرضات الخاصة بالر عاية لمرضي الغذاء بالأنبوبة الأنفمعدية \\ د/ نبيلة أحمد بدير- د/ أمل بكر أبوا لعطا - م.م مريم صبري شهاب \\ أستاذ التصريض الباطني والجر/حيـ كلية التهريض- جامعة الاسكندرية- مدرس التصريض \\ الباطني و الجر/حي_ كلية التمربض- جامعة بورسعبل- مدرس مساعد التهريض الباطني \\ و الجر/حي_ كلية التمريض- جامعة بورسعبد}

\section{مقدمة}

تهدف هذه الرسالة إلي نأثثر البرنامج التعليمي علي معلومات الممرضات الخاصة بالرعاية لمرضي الغذاء بالأنبوبة الأنف معدية ، وقد أجريت هذه الدراسة علي الممرضات التي يقمن بالعناية التمريضية بقسم العناية المركزة بمستشفي الأزهر الجامعي بدمياط وعددهن 30 ممرضة ـ وتم جمع البيانات من خلال استمارة استبيان

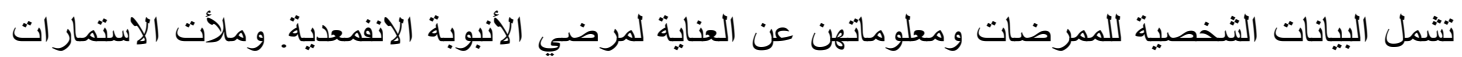

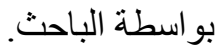

وقد أظهرت النتائج نأثير ا ذو دلالة احصائية واضحة علي معلومات الممرضات بعد البرنامج في كل ما يتعلق بالر عاية لمرضي الغذاء بالأنبوبة الانفمعدية وذلك بعد مقارنة النتائج قبل وبعد البرنامج. كما اظهرت الدراسة عدم وجود علاقة ما بين معلومات الممرضات و اعمار هن، سنوات الخبرة ومستوي التعليم. وقد اوصت الدر استة بأهمية تصميم بر امج تعليمية مستمرة لإعطاء معلومات عن التغذية عبر الانبوبة الانف معدية لتحسين معلومات الممرضات لتحقيق جودة عالية من الرعاية التمريضية لمريض الغذاء بالانبوبة الانفمعدية.

الكلمات الدالة:- الانبوبة الانفمعدية ، الممرضات، البرنامج التعليمي، معلومات، تقييم، التغذية الانبوبية 